\title{
Tıbbi Öneme Sahip Hatmiler İçin Etkili Bir Çimlendirme Yöntemi: Tohum Kabuğuna Çentik Atılması
}

\author{
Abdulhamit BATTAL ${ }^{1 *}$, Gül GÖRMEZ ${ }^{2}$, Musa TÜRKER ${ }^{3}$ \\ ${ }^{l}$ Van Yüzüncü Yll Üniversitesi, Farmasötik Biyoteknoloji Anabilim Dal,, Van \\ ${ }^{2}$ Van Yüzüncü Yll Üniversitesi, Moleküler Biyoloji ve Genetik Anabilim Dal, Van \\ ${ }^{3}$ Yıldız Teknik Üniversitesi, Biyomühendislik Bölümü, İstanbul \\ (ORCID: 0000-0001-6098-3908) (ORCID: 0000-0001-6980-4988) (ORCID: 0000-0003-3195-1119)
}

\begin{abstract}
$\ddot{O} z$
Malvaceae familyasının üyelerinden biri olan Alcea cinsi tıbbi öneme sahip bazı türleri içermektedir. Alcea kurdica Alef. (Deve gülü Hatmi) tonsilite, gastrik ülsere, zatürreye, boşaltım sistemi enfeksiyonlarına ve saç kırana karşı kullanılan tıbbi bir bitkidir. Bu çalışmanın amacı, deve gülü hatmi bitkisi için steril şartlar altında etkili bir çimlendirme yönteminin geliştirilmesi ve bu bitkinin doku kültürü çalışmalarında kullanılabilir hale getirilmesidir. $\mathrm{Bu}$ amaç için, steril bir ajan olan sodyum hipokloritin üç farklı konsantrasyonu ( $\% 5, \% 7.5 \mathrm{ve} \% 10), 42^{\circ} \mathrm{C}$ sıcaklıkta inkübasyonu ve tohum kabuğunun bistüri ile çentiklenmesi uygulamaları test edilmiştir. \%5 ve \%7.5 sodyum hipoklorit konsantrasyonlarının sterilizasyon için yeterli olmadığı belirlenirken, \%10 sodyum hipoklorit konsantrasyonun ise yeterli olduğu gözlenmiştir. Çimlenme oranları sonuçlarına göre, kabuğu çentiklenen tohumlar hızlıca çimlenirken, $42^{\circ} \mathrm{C}$ de inkübasyonun çimlenmeyi etkilemediği gözlenmiştir. Yedinci günde, kotiledon, kotiledon sapı ve hipokotil dokuları doku kültürü için kullanılabilir duruma gelmiştir. Sekizinci günde, yapraklar oluşmaya başlamıştır. Yaprak, yaprak sapı ve sürgün ucu eksplantları ise otuzuncu günde doku kültüründe kullanılabilecek duruma gelmiş̧ir. Sonuç olarak, bu çalışma ile tıbbi öneme sahip deve gülü hatmi için etkili bir çimlendirme yöntemi geliştirilmiş̧ir.
\end{abstract}

Anahtar kelimeler: Çimlenme Oranı, Hatmi, Alcea.

\section{The Efficient Germination Method For Marhsmallows With Medicinal Importance: The Nicking on Seed Coat}

\begin{abstract}
The genus Alcea one of the member of Malvaceae family includes some species having medicinal importance. Alcea kurdica Alef. (Deve gülü Marshmallow) is a medicinal plant used against tonsils, gastric ulcers, pneumonia, excretory system infections and pelade. The aim of this study was to develope an efficient germination method under sterile conditions and to make the plant suitable for tissue culture studies. For this purpose, three different concentrations $(5 \%, 7.5 \%$ and $10 \%)$ of the sodium hypochlorite which is a sterilizing agent, $42^{\circ} \mathrm{C}$ incubation and nicking on the seed coat with blade were tested. While 5\% and 7.5\% of sodium hypochlorite concentrations were not sufficient for sterilization, $10 \%$ of sodium hypochlorite concentration was observed to be sufficient. According to the results of the germination index, while the seeds nicked on coat were easily germinated, it was observed that incubation at $42^{\circ} \mathrm{C}$ did not affect the germination. On the seventh day, cotyledon, cotyledonary node and hypocotyl tissues were ready to use for tissue culture. On the eighth day, leaves began to form. Leaf, petiole and shoot tip explants were available to use in tissue culture on the thirtieth day. As a result, an efficient germination method for deve gülü marshmallow having medicinal importance was developed with this study.
\end{abstract}

Keywords: Germination Index, Marshmallow, Alcea.

*Sorumlu yazar: abdulhamitbattal@yyu.edu.tr

Geliş Tarihi: 25.03.2019, Kabul Tarihi: 29.07.2019 


\section{Giriş}

Tıbbi öneme sahip Alcea cinsi Malvaceae familyasının üyelerindendir. En çok bilineni Çin Halk Cumhuriyeti'nin güney batı bölgelerinden dünyanın bir çok bölgesine yayılan Alcea rosea L. türüdür [1]. Yaprakları, çiçekleri, gövdesi ve kökleri insanlar tarafından tüketilmektedir [2-4]. Taç yaprakları ve tomurcukları salatalara katılarak tüketilirken, taze yaprakları pişirilerek veya pişirilmeden yenmektedir [5]. Ayrıca, taç yapraklarındaki renkler konfeksiyon ürünlerinde, reçellerde, jölelerde ve alkolsüz içeceklerde gıda katkısı olarak kullanılmaktadır [2].

Müsilaj, glukuronik asit, galakturonik asit, ramnoz, galaktoz, pectin, ferulik asit, valinik asit, komarik asit, p-hidroksibenzoik asit ve kuersetin gibi biyoaktif maddeleri içerirken tohumlarında da malvalik, strekulik, miristik, palmitik, stearik, linoleik, oleik ve linolenik yağ asitlerini içermektedir [69]. A.rosea'nın antiproliferatif aktivitesi, anti-influenza etkisi, antioksidan özelliği ve antiülser aktivitesi gibi özellikleri yapılan çalışmalar ile ortaya konmuştur [10-13].

Tıbbi bitkilerin kotiledon, hipokotil, yaprak, yaprak sapı, nod ve sürgün ucu gibi kısımları eksplant kaynağı olarak kullanılarak çoğaltılması bitki doku kültürü yoluyla mümkündür. Etkili bir rejenerasyon sisteminin oluşturulması doku kültürü çalışmaları için önemlidir. Bitki doku kültürü çalışmalarında kullanılacak eksplant kaynağı, tipi ve eksplantın tazeleği mikroçoğaltım çalışmaları için önem arz etmektedir. Aynı familyadan olan ve tıbbi öneme sahip Althae officinalis L. (Hatmi) ile yapılan çalışmalarda genellikle ya botanik bahçelerinde yetiştirilen bitkilerden elde edilen kaynaklar ya da steril şartlar altında tohumlardan çimlendirilen bitkilerden elde edilen ekpslantlar kullanılmıştır [14-16]. Fakat, botanik bahçelerinden temin edilen bitkiler steril şartlar altında büyütülmediğinden kontaminasyona oldukça açıktırlar. Bu bitkilerin sterilizasyonu için civa klorür gibi doğaya zararlı kimyasallar sıklıkla kullanılmaktadır [14, 15]. Aynı zamanda, çevresel stres faktörleriyle birlikte vejetasyon dönemlerinin etkisiyle birlikte fizyolojik durumları da bitkiden bitkiye farklılık gösterebilmektedir. Bu faktörler de tıbbi bitkiler için oluşturulacak rejenerasyon sistemini olumsuz etkilemektedir.

Deve gülü hatmi bitkisi Alcea cinsine ait İran'ın batısında ve Irak'ın kuzeyinde tonsilite, gastrik ülsere, zatürreye, boşaltım sistemi enfeksiyonlarına ve saç kırana karşı kullanılan tıbbi bir bitkidir [17, 18]. Deve gülü bitkisinin kurutulmuş sulu ekstresinin antimikrobiyal ve antioksidan aktiviteye sahip olduğu gösterilmiştir [19]. Althae officinallis L. için önerilen bir çimlendirme yöntemi bulunurken, tıbbi amaçlı kullanılan deve gülü hatmi için doku kültürü çalışmalarında kullanılabilecek bir çimlendirme prosedürü bulunmamaktadır. Bazı hatmi türlerinde çimlenme durumları sıkıntılı olmakta ve fiziksel veya kimyasal muamele gerektirebilmektedir $[20,21]$. Yapılan ön çalışmalarda, deve gülü hatmi tohumları in vitro doku kültüründe ve toprakta çimlendiririlmeye çalışıldı fakat çimlenme gözlenmedi. $\mathrm{Bu}$ çalışmanın amacı, halk hekimliğinde kullanılan deve gülü bitkisi için etkili bir çimlendirme yöntemi oluşturmak ve bitki doku kültürü çalışmalarında kullanılabilecek eksplantların steril şartlar altında üretilmesidir.

\section{Materyal ve Metot}

\subsection{Kimyasallar ve Cihazlar}

Çalışmada Murashige ve Skoog (MS) besiyeri, sodyum hipoklorit, hidroklorik asit, sodyum hidroksit ve bitkiler için agar kimyasalları kullanılırken, biyogüvenlik kabini, etüv, otoklav, pH metre, manyetik ısıtıcılı karıştırıcı, orbital çalkalayıcı ve cam boncuklu sterilizatör cihazları kullanılmıştır.

\subsection{Bitki Materyali}

Çalışmada Van yöresinden toplanan deve gülü hatmi türünün tohumları kullanılmıştır. Tohumlar, 2017 yılının Ağustos ve Eylül aylarında toplanmıştır. Laboratuvara getirilen tohumlar yabancı maddeler uzaklaştırıldıktan sonra kurutma kağıtları üzerine serildi ve kurutuldu. Toz ve zararlıların uzaklaştırıldığ kurutulan tohumlar paketlenerek $+4^{\circ} \mathrm{C}$ de muhafaza edilmiştir. 


\subsection{Tohumların Yüzey Sterilizasyonu}

Tohumlar sterilizasyona tabi tutulmadan önce etrafindaki kanatlar el ile çıkarılarak uzaklaştırılmıştır. Tohumların sterilizasyonu için sodyum hipokloritin $(\mathrm{NaOCl})$ farklı konsantrasyonları (\%5, \%7,5 ve \%10) kullanılmıştır. 20 dakika bu konsantrasyonlarda inkübatörde $25^{\circ} \mathrm{C}$ de bekletilen tohumlar, daha sonra biyogüvenlik kabini içerisinde steril distile su ile 4-5 kez yıkandıktan sonra \%70 etil alkol ile 30 saniye muamele edilmiştir. Steril distile su ile $4-5 \mathrm{kez}$ tekrar yıkanmıştır. $42^{\circ} \mathrm{C}$ sıcaklıkta inkübasyonun ve tohum kabuğunun çentiklenerek zedelenmesinin deve gülü tohumlarının bitki doku kültüründe çimlenmesine olan etkisinin araştırılması için tohumlar her bir sodyum hipoklorit konsantrasyonu (\%5, \% 7.5 ve \%10) için 3 gruba ayırılmıştır (Tablo 1). Yüzey sterilizasyonu uygulanan tohumların çimlenmeleri sırasında bakteri ve mantar üremesi takip edilmiştir.

Tablo 1. Deve gülü tohumlarının uygulama grupları

\begin{tabular}{|c|c|}
\hline Grup Ad1 & $\begin{array}{l}\text { Uygulama } \\
\end{array}$ \\
\hline $5-\mathrm{SH}$ & \% 5 Sodyum hipoklorit ile yüzey sterilizasyonu yapılmış tohumlar. \\
\hline $5-\mathrm{SH}+42^{\circ} \mathrm{C}$ & $\begin{array}{l}\text { \% } 5 \text { Sodyum hipoklorit ile yüzey sterilizasyonu yapılmış ve } 24 \text { saat } \\
42^{\circ} \mathrm{C} \text { de inkübe edilmiş tohumlar. }\end{array}$ \\
\hline $5-\mathrm{SH}+42^{\circ} \mathrm{C}+\mathrm{Z}$ & $\begin{array}{l}\text { \% } 5 \text { Sodyum hipoklorit ile yüzey sterilizasyonu yapılmış, } 24 \text { saat } 42^{\circ} \mathrm{C} \\
\text { de inkübe edilmiş ve tohum kabuğu bistüri yardımıla çentiklenmiş } \\
\text { tohumlar. İnkübasyon sonrası çentiklenmeden önce tohumlar aynı } \\
\text { sodyum hipoklorit ile } 10 \text { dakika yüzey sterilizasyonu uygulanmıştır. }\end{array}$ \\
\hline 7.5-SH & \% 7.5 Sodyum hipoklorit ile yüzey sterilizasyonu yapılmış tohumlar. \\
\hline 7.5-SH+42 ${ }^{\circ} \mathrm{C}$ & $\begin{array}{l}\% 7.5 \text { Sodyum hipoklorit ile yüzey sterilizasyonu yapılmış ve } 24 \text { saat } \\
42^{\circ} \mathrm{C} \text { de inkübe edilmiş tohumlar. }\end{array}$ \\
\hline 7.5-SH $+42^{\circ} \mathrm{C}+\mathrm{Z}$ & $\begin{array}{l}\text { \% } 7.5 \text { Sodyum hipoklorit ile yüzey sterilizasyonu yapılmış, } 24 \text { saat } \\
42^{\circ} \mathrm{C} \text { de inkübe edilmiş ve tohum kabuğu bistüri yardımıyla } \\
\text { çentiklenmiş tohumlar. İnkübasyon sonrası çentiklenmeden önce } \\
\text { tohumlar aynı sodyum hipoklorit ile } 10 \text { dakika yüzey sterilizasyonu } \\
\text { uygulanmıştır. }\end{array}$ \\
\hline 10-SH & \% 10 Sodyum hipoklorit ile yüzey sterilizasyonu yapılmış tohumlar. \\
\hline $10-\mathrm{SH}+42^{\circ} \mathrm{C}$ & $\begin{array}{l}\% 10 \text { Sodyum hipoklorit ile yüzey sterilizasyonu yapılmış ve } 24 \text { saat } \\
42^{\circ} \mathrm{C} \text { de inkübe edilmiş tohumlar. }\end{array}$ \\
\hline $10-\mathrm{SH}+42^{\circ} \mathrm{C}+\mathrm{Z}$ & $\begin{array}{l}\% 10 \text { Sodyum hipoklorit ile yüzey sterilizasyonu yapılmış, } 24 \text { saat } \\
42^{\circ} \mathrm{C} \text { de inkübe edilmiş ve tohum kabuğu bistüri yardımıyla } \\
\text { çentiklenmiş tohumlar. İnkübasyon sonrası çentiklenmeden önce } \\
\text { tohumlar aynı sodyum hipoklorit ile } 10 \text { dakika yüzey sterilizasyonu } \\
\text { uygulanmıştır. }\end{array}$ \\
\hline
\end{tabular}

\subsection{Deve Gülü Tohumlarının İnkübe Edileceği MS besiyerlerinin Hazırlanması}

Besiyeri hazırlamak için $2.2 \mathrm{~g} / \mathrm{L}$ MS besiyeri ve $15 \mathrm{~g} / \mathrm{L}$ sakaroz tartılarak distile su içerisinde çözdürülmüş ve pH 5.8 e ayarlanmıştır. Daha sonra $8 \mathrm{~g} / \mathrm{L}$ bitki agarı tartılarak çözeltiye eklenmiştir. Hazırlanan besiyeri otoklavlanmışır ve biyogüvenlik kabini içerisinde steril $90 \mathrm{~mm}$ petri kutularına döküldü. Her gruptan 10 adet tohum 1/2 MS besiyerine konuldu ve bitki doku kültürü odasında 16/8 saat fotoperiyotta çimlendirilmiştir.

\subsection{Deve Gülü Tohumlarının Çimlendirilmesi}

Çimlenme durumları 1., 2., 3., 5., 10. ve 30. sürelerinde takip edilerek aşağıda ki formüle göre 5. ve 30. gündeki \% çimlenme oranları belirlenmiştir.

\% Çimlenme Oranı $(\mathrm{C} O)=($ Çimlenmiş Tohum Sayısı/Ekilmiş Tohum Sayısı) X 100 


\section{6. İstatistik Analizi}

Deneyler en az üç tekrar olarak gerçekleştirildi ve istatistiki analizler Minitab12 One-Way ANOVA kullanılarak yapılmıştır. Gruplar arasında yapılan istatistiki karşılaştırmalarda $\mathrm{p}<0.05$ değerleri istatistiki olarak anlamlı değişiklikler olarak değerlendirilmiştir.

\section{Bulgular ve Tartışma}

\subsection{Farklı Sodyum Hipoklorit Konsantrasyonlarının Yüzey Sterilizasyonu Etkilerinin Değerlendirilmesi}

Çalışmada sodyum hipokloritin üç farklı konsantrasyonunun (\%5, \%7.5 ve \%10) deve gülü bitkisinin tohumlarının bitki doku kültürü ortamları kullanılarak çimlendirilmesinde sterilizasyona etkisi değerlendirilmiştir. Bitki doku kültüründe kullanılacak eksplant kaynaklarının bolluğu önemlidir. Bitkilerin kök, gövde, kotiledonlar, yapraklar, embriyo, kotiledon sap1 ve yaprak sap1 gibi farkl1 kısımları bitki doku kültürü çalışmalarında eksplant kaynağı olarak kullanılabilmektedir [14,15]. Bundan dolayı, bitkilerin yapay bitki doku kültürü ortamları kullanılarak steril olarak çimlendirilmesi yeterli eksplant kaynağının sağlanması için oldukça önemlidir. 5-SH gruplarında 2. Gün sonunda 5-SH ve $5-\mathrm{SH}+42^{\circ} \mathrm{C}+\mathrm{Z}$ gruplarında bakteri ve mantar üremesi belirlenirken, 3. Gün sonunda $5-\mathrm{SH}+42^{\circ} \mathrm{C}$ grupta da bakteri ve mantar ürediği tespit edilmiştir. \%7.5 SH uygulanan gruplarda 1 . Günün sonunda, $7.5-\mathrm{SH}+42^{\circ} \mathrm{C}+\mathrm{Z}$ grubu tohumların bulunduğu besiyerinde mantar ürediği gözlendi ve 3 . Gün sonunda 7.5-SH, 7.5-SH $+42^{\circ} \mathrm{C}$ ve $7.5-\mathrm{SH}+42^{\circ} \mathrm{C}+\mathrm{Z}$ gruplarında bakteri ve mantar üremesi belirlenmiştir (Şekil 1). Bakteri ve mantar ile kontamine olan besiyerleri 5. Güne kadar bekletilmiş ve çimlenme oranları belirlendikten sonra otoklav ile imha edilmiştir. \% 10 sodyum hipoklorit uygulanan gruplarda ise 30 . Güne kadar herhangi bir kontaminasyon görülmemiştir. Deve gülü tohumlarının \% 10 sodyum hipoklorit ile 20 dakika uygulanmasının deve gülü bitkisi tohumlarında sterilizasyonun sağlanması için yeterli olduğu belirlenmiştir. (Tablo 2)

Tohumların yüzey sterilizasyonu için genellikle etanol, sodyum hipoklorit $(\mathrm{NaOCl})$, Tween-20 ve civa klorür $\left(\mathrm{HgCl}_{2}\right)$ gibi sterilizasyon ajanların kullanılması önerilmektedir [22, 23]. Althaea officinalis L. bitkisinin tohumları fungisit ve çok amaçlı deterjan ile muamele edildikten sonra $\% 0.1$ civa klorür $\left(\mathrm{HgCl}_{2}\right)$ kullanılarak yüzey sterilizasyonu yapıldıktan sonra çimlendirilmiş ve nodları doku kültürü çalışmaları için kullanılmıştır [16]. Aynı bitkinin kullanıldığı başka bir çalışmada ise $\mathrm{HgCl}_{2}$, $\mathrm{NaOCl}$, etanol ve Tween-20 sterilizasyon ajanlarının farklı konsantrasyon ve sürelerde uygulaması yapılmış ve \%14.66 (\%0.3 $\mathrm{HgCl}_{2}, 7$ dakika) ve \%85.33 (Steril distile su, 20 dakika) arasında değişen kontaminasyon oranları gözlendiği, optimum sterilizasyon durumunun 5 dakika $\% 4 \mathrm{NaOCl}$ kullanılmasıyla elde edildiği rapor edilmiştir [24]. Aynı çalışmada, NaOCl'in \%4 konsantrasyonunun 10 dakika uygulamasınında kontaminasyona sebep olduğu bildirilmiştir. Yapılan bu çalışmada ise deve gülü hatmi için \% 10 sodyum hipoklorit ile 10 dakika ve sonrasında $\% 70$ etanol ile 30 saniye muamelenin sterilizasyon için yeterli olduğu bulunmuştur.

Çizelge 2. Farklı sodyum hipoklorit uygulanan deve gülü tohumlarında 5.Gün sonunda gözlenen kontaminasyonlar

\begin{tabular}{ccc}
\hline Uygulamalar & Bakteri Kontaminasyonu & Mantar Kontaminasyonu \\
\hline $5-\mathrm{SH}$ & + & + \\
$5-\mathrm{SH}+42^{\circ} \mathrm{C}$ & + & + \\
$5-\mathrm{SH}+42{ }^{\circ} \mathrm{C}+\mathrm{Z}$ & + & + \\
$7.5-\mathrm{SH}$ & + & + \\
$7.5-\mathrm{SH}+42^{\circ} \mathrm{C}$ & + & + \\
$7.5-\mathrm{SH}+42^{\circ} \mathrm{C}+\mathrm{Z}$ & + & + \\
$10-\mathrm{SH}$ & - & - \\
$10-\mathrm{SH}+42^{\circ} \mathrm{C}$ & - & - \\
$10-\mathrm{SH}+42^{\circ} \mathrm{C}+\mathrm{Z}$ & - & - \\
\hline
\end{tabular}



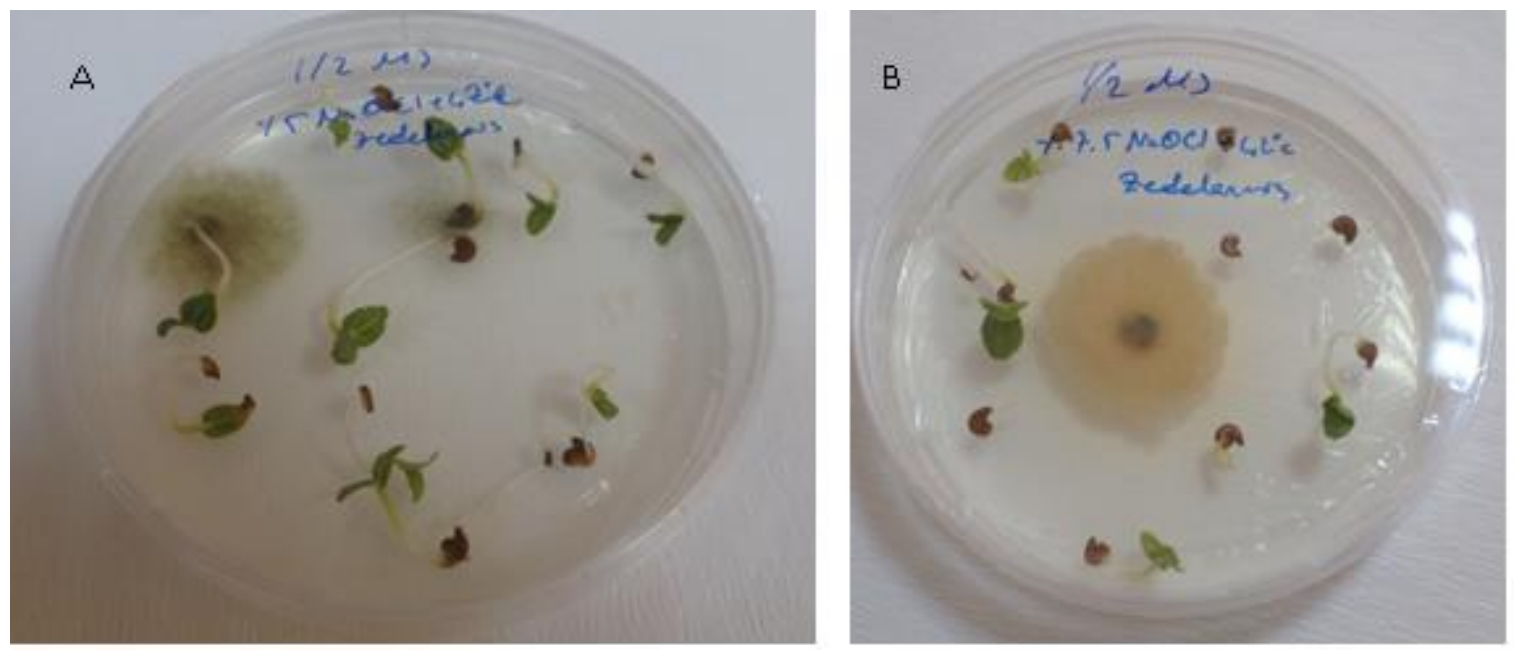

Şekil 1. $\% 5$ ve $\%$ 7.5 $\mathrm{SH}$ uygulamalarında görülen kontaminasyonlar. A:5-SH+42 ${ }^{\circ} \mathrm{C}+\mathrm{Z}$; B:7.5-SH+42 ${ }^{\circ} \mathrm{C}+\mathrm{Z}$ uygulamaları.

\subsection{Deve Gülü Bitkisi Tohumlarının Çimlenme Oranı}

Yapılan ön çalışmalarda, çentik atılmamış tohumlara $\mathrm{HgCl}_{2}$, etanol ve sodyum hipoklorit gibi sterilizasyon ajanlarını farklı konsantrasyonları farklı süreler ile test edilmiş ve çimlenme gözlenmemiştir. Daha sonra bistüri ile çentik atılan deve gülü bitkisinin tohumlarının $1 / 2$ MS besiyerinde çimlenme durumları 1., 2., 5., 10. ve 30. günlerde gözlenmiş̧ir. 5. Gün çimlenme oranları bütün uygulamalar için hesaplanırken, 30. gün çimlenme oranı sadece kontaminasyonun olmadığ $1 \% 10$ sodyum hipoklorit ile sterilize edilen gruplar için hesaplanmıştır. Tohumların ekiminden itibaren 1.gün sonunda sadece meyve kabuğu bistüriyle zedelenen tohum gruplarında çimlenmenin başladığ gözlenmiştir. $42^{\circ} \mathrm{C}$ sicaklıkta inkübe edilen ve meyve kabuğu zedelenmeyen ve sadece sodyum hipoklorit uygulanan gruplarda tohumlar çimlenmemiştir. 5.Gün çimlenme oranı en yüksek $90.00 \pm 10.00$ oran ile $5-\mathrm{SH}+42^{\circ} \mathrm{C}+\mathrm{Z}$ uygulamasında belirlenmiştir (Çizelge 3). Fakat, bu uygulamada hem bakteri hem de mantar oluştuğu gözlenmiştir. $7.5-\mathrm{SH}+42^{\circ} \mathrm{C}+\mathrm{Z}(\% 66.67 \pm 25.166)$ ve 10 $\mathrm{SH}+42^{\circ} \mathrm{C}+\mathrm{Z}(\% 66.67 \pm 20.817)$ uygulamalarında da 5. Gün sonunda çimlenme gözlenirken, 7.5$\mathrm{SH}+42^{\circ} \mathrm{C}+\mathrm{Z}$ uygulamasında bakteri ve mantar kontaminasyonu oluştu (Tablo 2 ve Şekil 1). 10 $\mathrm{SH}+42^{\circ} \mathrm{C}+\mathrm{Z}$ uygulamasında ise kontaminasyon gözlenmemiştir. 5.Gün sonunda kontaminasyon gözlenen $\% 5$ ve $\% 7.5 \mathrm{SH}$ uygulamaları sonlandırılmış ve denemeye kontaminasyon oluşmayan $\% 10$ SH grupları ile devam edilmiştir. 30.gün sonunda sadece 10-SH uygulamasında çimlenme oranı $\% 3.33 \pm 5.774$ iken, $10-\mathrm{SH}+42^{\circ} \mathrm{C}+\mathrm{Z}$ uygulanmasında çimlenme oranı \%86.67 \pm 5.774 olarak hesaplanmıştır (Tablo 3 ve Şekil 2). Sonuçlar değerlendirildiğinde, tohumların $42^{\circ} \mathrm{C}$ sicaklıkta 24 saat inkübasyonunun deve gülü bitkisinin çimlenmesini teşvik etmediği belirlenirken, meyve kabukları zedelenmiş tohumların ise yüksek çimlenme oranlarına sahip olduğu belirlenmiştir. Tohum kabuğunun zedelenmesiyle tohumların su alımı hızlanmış ve çimlenme için gereken enzim aktivitelerinin başlaması sağlanmıştır.

Çimlenen tohumlar hızlıca filizlenmiş ve kotiledonlar oluşmuştur. Çimlenmeden 1 hafta sonra filizlerin kotiledon, kotiledon sapları, hipokotil ve epikotil kısımları doku kültüründe eksplant kaynağı olarak kullanılmaya hazır hale gelmiştir. Yapraklar, 8.Günde oluşmaya başlamış ve 30.Gün sonunda yaprak, yaprak sapı ve sürgün ucu eksplantları doku kültüründe kullanılabilecek duruma gelmiştir (Şekil $3)$.

Althea officinalis L. ile yapılan bir çalışmada çimlenme oranının oldukça düşük olduğu bildirilmiştir [20]. Aynı türden Alcea aucheri (Boiss.) Alef. ile yapılan bir çalışmada farklı sülfürik asit konsantrasyonlarının ve uygulama sürelerinin, giberillik asitin farklı konsantrasyonların ve kum zımparasının farklı uygulama sürelerinin bitki tohumlarının çimlenmesine etkisi incelenmiş ve en yüksek çimlenme oranının (\% 42) 5 dakika kum zımparası uygulamasıyla elde edildiği bildirilmiştir [21]. Gülhatmi bitkisi için oluşturulan etkili bir çimlendirme prosedürünün rapor edildiği çalışmada en yüksek çimlenme oranı \%76 ile steril mineral su kullanılarak elde edildiği ve en düşük çimlenme oranın ise $\% 3$ sükroz ilaveli agar ile katılaştırılmış MS besiyerinde $\% 28$ bulunduğu bildirilmiştir [24]. Tıbbi bir bitki olan Rheum ribes L. ile yapılan bir çalışmada ise sülfürik asit, giberellik asit, kalsiyum klorür 
ve potasyum nitratın farklı konsantrasyonları farklı stratifikasyon sürelerinde test edilmiş ve en yüksek çimlenme oranın (\% 57.3) giberellik asit ile 25 gün $4^{\circ} \mathrm{C}$ de aydınlıkta inkübe edilen örneklerde bulunduğu bildirilmiştir [25]. Sonuçlar değerlendirildiğinde, hatmi türlerinden biri olan deve gülü bitkisi \% 90 a yakın bir oranda çimlendirilmesi gerçekleştirilmiştir.

Tablo 3. Deve Gülü 5.Gün ve 30.Gün Çimlenme oranları

\begin{tabular}{|c|c|c|}
\hline \multirow[b]{2}{*}{ Uygulamalar } & \multicolumn{2}{|c|}{ Çimlenme Oranı (\%) Ortalama \pm Standart Sapma } \\
\hline & 5.Gün & 30.Gün \\
\hline $5-\mathrm{SH}$ & $3.33 \pm 5,774^{\mathrm{a}}$ & N.D \\
\hline $5-\mathrm{SH}+42^{\circ} \mathrm{C}$ & $0.00 \pm 0.000^{\mathrm{a}}$ & N.D \\
\hline $5-\mathrm{SH}+42^{\circ} \mathrm{C}+\mathrm{Z}$ & $90.00 \pm 10.00^{\mathrm{ab}}$ & N.D \\
\hline 7.5-SH & $3.33 \pm 5.774^{\mathrm{a}}$ & N.D \\
\hline 7.5-SH+42 ${ }^{\circ} \mathrm{C}$ & $0.00 \pm 0.000$ & N.D \\
\hline 7.5-SH $+42^{\circ} \mathrm{C}+\mathrm{Z}$ & $66.67 \pm 25.166^{\mathrm{ab}}$ & N.D \\
\hline $10-\mathrm{SH}$ & $0.00 \pm 0.000^{\mathrm{a}}$ & $3.33 \pm 5.774^{\mathrm{a}}$ \\
\hline $10-\mathrm{SH}+42^{\circ} \mathrm{C}$ & $0.00 \pm 0.000^{\mathrm{a}}$ & $0.00 \pm 0.000^{\mathrm{a}}$ \\
\hline $10-\mathrm{SH}+42^{\circ} \mathrm{C}+\mathrm{Z}$ & $66.67 \pm 20.817^{\mathrm{ab}}$ & $86.67 \pm 5.774^{\mathrm{ab}}$ \\
\hline
\end{tabular}

Aynı sütunda ki farklı harfler ortalamalar arasındaki istatistiki olarak p $<0.05$ farklılığg belirtir.

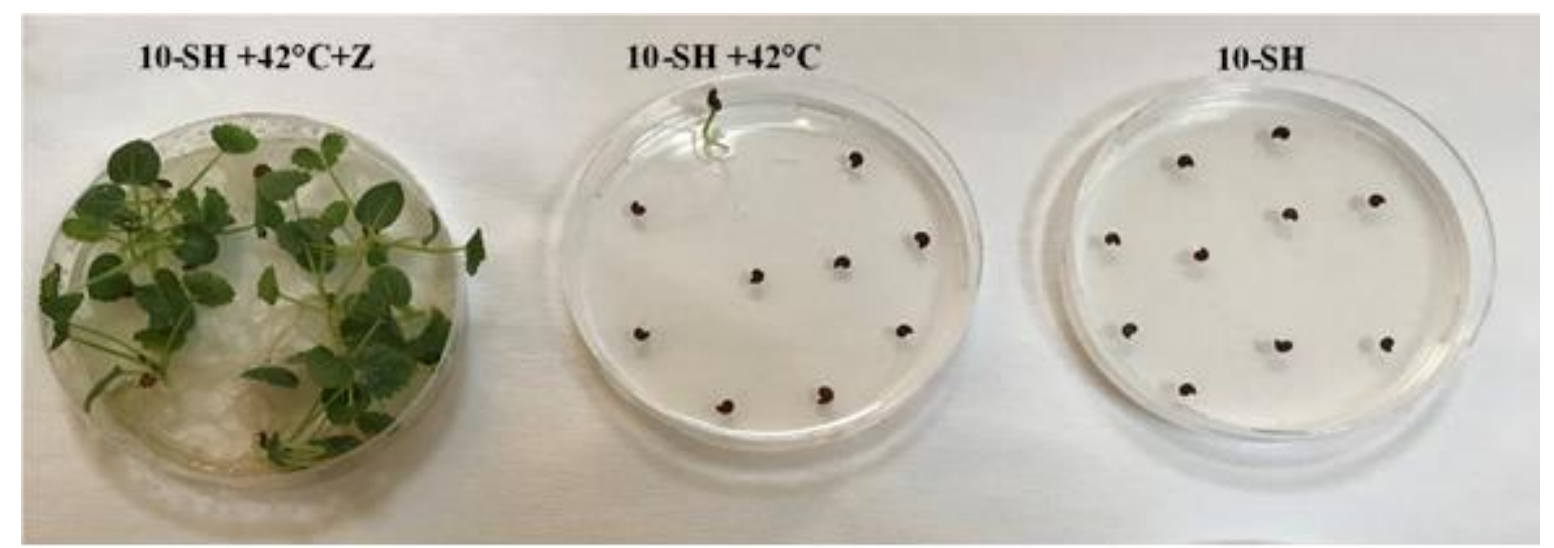

Şekil 2. \%10 SH uygulamalarının 30.Gün çimlenme durumları 


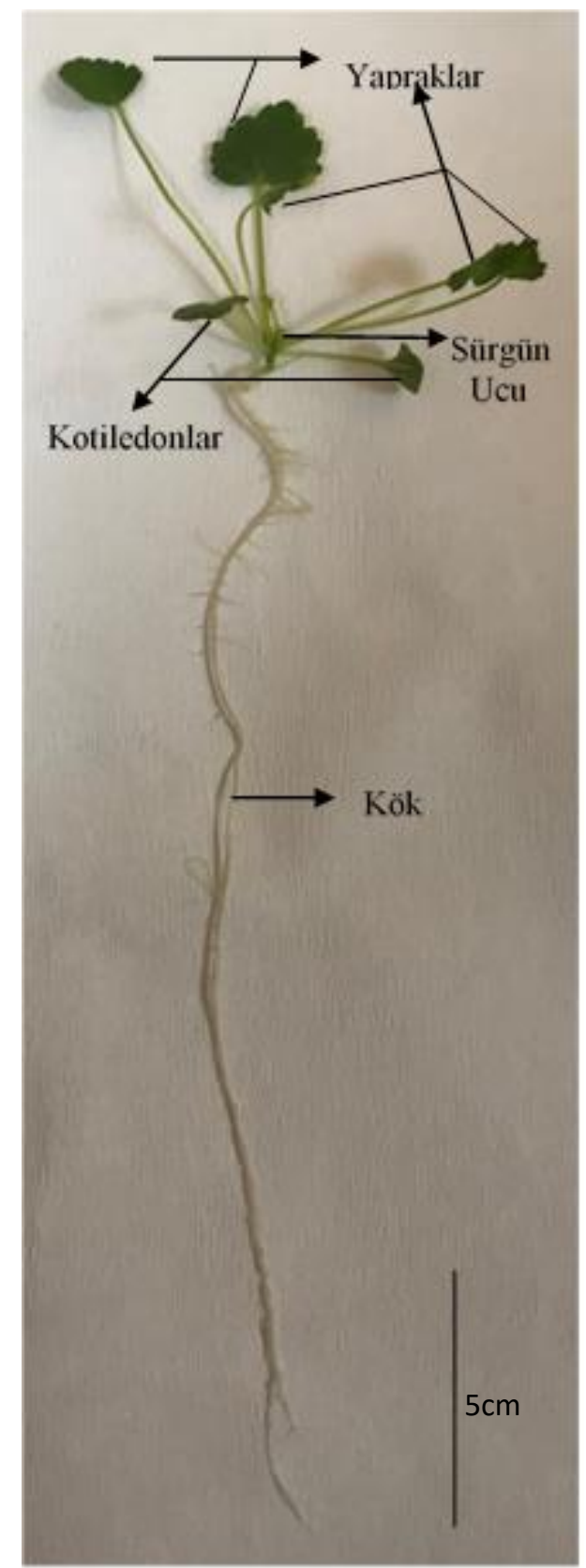

Şekil 3. 30.Gün sonunda çimlenen deve gülü bitkiciği

\section{Sonuç ve Öneriler}

Sonuç olarak, deve gülü bitkisi için tohum kabuğunun çentiklenmesi ile etkili bir çimlendirme prosedürü geliştirilmiş olup bitki doku kültürü çalışmaları için sorunsuzca kullanılabilecek eksplant kaynaklarının elde edilebilmesi sağlanmıştır. Geliştirilen çimlendirme yönteminin diğer hatmi türlerinin yanında çimlenme oranı düşük diğer tıbbi bitkiler için uygulanabilirliği test edilebilir.

\section{Teşekkür}

Deve gülü tohumlarının toplanmasına yardımcı olan Doç. Dr. Abdullah Dalar ve Dr. Muzaffer Mükemre'ye ve teşhisine yardımcı olan Prof. Dr. Murat Ünal'a katkılarından dolayı teșekkür ederiz. Bu çalışma Van Yüzüncü Yıl Üniversitesi BAP Koordinatörlüğü FDK-2017-6160 proje kodu ile desteklenmiştir. 


\section{Kaynaklar}

[1] Ya T., Gilbert M.G., Dorr L.J. 2007. Malvaceae in Flora of China, Edited by Wu Z.Y, Raven PH, Hong DY, Vol.12 (Hippocastanaceae through Theaceae), Science Press, Beijing / Missouri Botanical Garden Press, St. Louis, 265-298.

[2] Kasumov M.A. 1984. Red dye from the hollyhock and its use in food industry. DokladyAkademiia nauk Azerbaidzhanskoi SSR, 40 (6): 76-79.

[3] Facciola S. 1990. Cornucopia: a source book of edible plants. Kampong Publications, 677s. California.

[4] Roberts M.J. 2000. Edible and medicinal flowers. Spearhead Press, 160s. Claremont.

[5] Lim T.K. 2014. Alcea rosea in Edible Medicinal and Non Medicinal Plants. Edited by Lim T.K., Vol: 8, Dordrecht, Springer, 292-299.

[6] Rakhimov D.A., Atkhamova S.K., Khvan A.M. 2007. Pectinic substances from Alcea rosea flowers. Chemistry of Natural Compounds, 43 (6): 685-686.

[7] Dudek M., Matławska I., Szkudlarek M., 2006. Phenolic acids in the flowers of Althaea rosea var. nigra. Acta Poloniae Pharmaceutica, 63 (3): 207-211.

[8] Daulatabad C.D. Jamkhandi AM. 2000. Althaea rosea seed oil-a rich source of ricinoleic acid. Journal of the Oil Technologists' Association of India, 32 (1): 8-9.

[9] Sherwani M.R.K., Chouhan S., Malik A., Parveen S., Sharma S. 2012. Isolation and characterization of cyclopropenoid fatty acids in Althaea rosea seed oil. International Journal of Research in Phytochemistry and Pharmacology, 2 (1): 52-54.

[10] Barnaulov O.D., Manicheva O.A., Trukhaleva N.A., Kozhina I.S., Fokina N.E., Salikhov S.A. 1985. Alcea-rosea a source of polysaccharides with anti-ulcer activity. Rastitel'nye Resursy, 21: 329-340.

[11] Mert T., Fafal T., Öztürk B. 2010. Antimicrobial and Cytotoxic Activities of the Extracts Obtained from the Flowers of Alcea Rosea L. Hacettepe University Journal of the Faculty of Pharmacy, 30 (1): 17-24.

[12] Yaglıoglu Sahin A., Eser F., Tekin S., Onal A. 2016. Antiproliferative activities of several plant extracts from Turkey on rat brain tumor and human cervix carcinoma cell lines. Frontiers in Life Science, 9 (1): 69-74.

[13] Kim M.S., Chathuranga K., Kim H., Lee J.S., Kim C.J. 2018. Anti-influenza properties of herbal extract of Althaea rosea in mice. Korean Journal of Veterinary Research, 58 (3): 153-158.

[14] Naz R., Anis M. 2012. Acceleration of adventitious shoots by interaction between exogenous hormone and adenine sulphate in Althaea officinalis L. Applied Biochemistry and Biotechnology, 168 (5): 1239-1255.

[15] Naz R., Anis M., Alatar A.A. 2017. Embling Production in Althaea officinalis L., Through Somatic Embryogenesis and Their Appraisal via Histological and Scanning Electron Microscopical Studies. Applied Biochemistry and Biotechnology, 182 (3): 1182-1197.

[16] Naz R., Anis M., Aref I.M., 2015. Management of cytokinin-auxin interactions for in vitro shoot proliferation of Althaea officinalis L.: a valuable medicinal plant. Rendiconti Lincei, 26 (3): 323334.

[17] Bouayed J., Piri K., Rammal H., Dicko A., Desor F., Younos C., Soulimani R. 2007. Comparative evaluation of the antioxidant potential of some Iranian medicinal plants. Food Chemistry, 104 (1): 364-368.

[18] Mati E., de Boer H. 2011. Ethnobotany and trade of medicinal plants in the Qaysari Market, Kurdish Autonomous Region, Iraq. Journal of Ethnopharmacology, 133 (2): 490-510.

[19] Qader S.W., Awad H.M. 2014. Evaluation of Antioxidant, Antimicrobial and Cytotoxicity of Alcea kurdica Alef. Jordan Journal of Biological Sciences, 147 (1572): 1-5.

[20] Kozlowski J., Szczyglewska D., Formanowiczowa H. 1989. Biology of germination of medicinal plants seeds. Pt. 14. Seeds of species from Malvaceae family: marsh mallow (Althea officinalis L.) and mallow (Malva silvestris L.). Herba Polonica, 2 (3): 99-107.

[21] Shooshtarian S., Salehi H. 2010. Enhancing Alcea aucheri (Boiss.) Alef. seed germination by application of some scarification treatments. Advances in Environmental Biology, 4 (2): 216-219. 
[22] Baiyeri K.P., Mbah B.N. 2006. Surface sterilization and duration of seed storage influenced emergence and seedling quality of African breadfruit (Treculia africana Decne). African Journal of Biotechnology, 5 (15): 1393-1396.

[23] Ramakrishna N., Lacey J., Smith J.E. 1991. Effect of surface sterilization, fumigation and gamma irradiation on the microflora and germination of barley seeds. International Journal of Food Microbiology, 13 (1): 47-54.

[24] Younesikelaki F.S., Ebrahimzadeh M.H., Desfardi M.K., Banala M., Marka R., Nanna R.S. 2016. Optimization of seed surface sterilization method and in vitro seed germination in Althaea officinalis (L.)-an important medicinal herb. Indian Journal of Science and Technology, 9: 1-6.

[25] Akin M., Ekin Z., Ozmen S., Kaya M. 2019. Seed Dormancy in Rheum ribes L. Collected from Natural Populations in Turkey. International Journal of Scientific and Technological Research, 5 (2): 183-192. 